\title{
MENGUBAH POLA PIKIR MASYARAKAT MENJADI LEBIH PRODUKTIF
}

\author{
Sri Nurlaily ${ }^{1}$, Haliamah Tussakdiah, Lutfi Amalia ${ }^{2}$ \\ srinurlaily@uika-bogor.ac.id \\ Dosen Fakultas Keguruan dan Ilmu Pendidikan ${ }^{1}$, Mahasiswa KKN Kelompok 30 Tahun \\ $2018^{2}$
}

\begin{abstract}
ABSTRAK
Tujuan dari kegiatan ini adalah mengembangkan, meningkatkan mutu dan keberlangsungan kegiatan pada bidang kesehatan, pendidikan, ekonomi, kelembagaan, dan pemberdayaan lingkungan. Selain itu juga memperluas program pemberdayaan masyarakat guna meningkatkan kemampuan melalui pemantapan fungsi keluarga. Desa Galuga Merupakan Salah satu desa Di Wilayah Kecamatan Cibungbulang Kabupaten Bogor Dengan Luas wilayah 170.5 Ha Yang Terbagi Dalam 4 Dusun, 6 Rukun Warga (RW) 13 Rukun Tetangga (RT). Sasaran dalam penelitian ini dilaksanakan di kampung Moyan RT 10/RW 05, Desa Galuga, dengan jumlah penduduk 6.068 jiwa yang terdiri dari 2.723 laki-laki dan 2.898 perempuan dengan jumlah kepala keluarga sebanyak $1.717 \mathrm{KK}$. Mata pencaharian masyarakat Desa Galuga di dominasi oleh buruh tani yang berjumlah 2.125 Orang. Desa Galuga secara demografis memiliki banyak potensi, diantaranya biang TPA (Tempat Pembuangan Akhir) yang dijadikan sebagai salah satu mata pencaharian masyarakat Galuga, perkebunan, peternakan dan kewirausahaan yang dapat dioptimalkan dalam usaha untuk pembangunan desa untuk meningkatkan perekonomian masyarakat desa tersebut selama ini belum dapat dioptimalkan dengan baik oleh masyarakat sekitar. Untuk mendukung hal tersebut, perlu juga dilakukan peningkatan dibidang kesehatan, pendidikan dan ekonomi sebagai dasar terbentuknya sumberdaya manusia yang berpotensi agar tercipta sumber daya masyarakat yang lebih baik.
\end{abstract}

Kata Kunci : Pola pikir, Masyarakat, Produktif.

PENDAHULUAN

\section{Latar Belakang}

Kuliah Kerja Nyata (KKN) merupakan salah satu mata kuliah intra kulikuler yang diselenggarakan oleh akademik diseluruh perguruan tinggi yang wajib diikuti oleh seluruh mahasiswa dengan bertujuan untuk meningkatkan kemampuan dan wawasan mahasiswa sebagai bekal hidup dimasyarakat setelah lulus nanti. Pada dasarnya, kuliah kerja nyatta (KKN) merupakan suatu bentuk pengabdian nyata seorang mahasiswa kepada masyarakat dengan seutuhnya. Lalu, setelah mendapatkan materi dibangku perkuliahan yang senantiasa dapat berguna dilingkungan masyarakat setempat. Kegiatan Kuliah Kerja Nyata (KKN) ini, mahasiswa mampu memberikan pengalaman berdasarkan ilmu pengetahuan umum, agama, teknologi, kesehatan dan ekonomi yang akan memecahkan seluruh permasalahan hidup yang terjadi dimasyarakat tersebut dan dapat menanggulanginya secara tepat dan 
mahasiswa pula bisa membenahi sarana dan prasarana masyarakat serta memberdayakan pembangunan sumber daya manusia dalam masyarakat tersebut, serta mahasiswa harus bersikap cerdas, cermat dan tangkas dalam menghadapi seluruh permasalahan yang akan dihadapi oleh mahasiswa dengan masyarakat setempat dalam meningkatkan potensi dan kinerja kemampuan mahasiswa itu secara berkelompok maupun individual. Universitas Ibn Khaldun Bogor (UIKA) sebagai salah satu lembaga pendidikan yang berada dikawasan Kota Bogor memiliki kewajiban untuk berperan serta secara aktif dalam pembangunan dibidang pemberdayaan lingkungan, kesehatan, pendidikan serta ekonomi. Peran serta tersebut bukan hanya dilakukan oleh mahasiswa saja namun juga masyarakat disekitar kampus atau masyarakat luas. Mahasiswa KKN juga mengadakan pertemuan secara rutin membahas program kerja. Ketika penerjunan ke lokasi KKN, para mahasiswa melakukan kegiatan observasi. Kegiatan ini dilakukan sebelum mahasiswa benar-benar terjun ke lokasi KKN. Kegiatan ini dilakukan untuk mengamati secara langsung terhadap situasi, kondisi, sarana, dan pasarana yang ada di lokasi KKN dalam hal ini guna mendukung proses kuliah kerja nyata di lokasi tersebut. Desa Galuga Merupakan Salah satu desa Di Wilayah Kecamatan Cibungbulang Kabupaten Bogor Dengan Luas wilayah $170.5 \mathrm{Ha}$ Yang Terbagi Dalam 4 Dusun, 6 Rukun Warga (RW) 13 Rukun Tetangga (RT). Sasaran dalam penelitian ini dilaksanakan di kampung Moyan RT 10/RW 05, Desa Galuga, dengan jumlah penduduk 6.068 jiwa yang terdiri dari 2.723 laki-laki dan 2.898 perempuan dengan jumlah kepala keluarga sebanyak 1.717 KK. Mata pencaharian masyarakat Desa Galuga di dominasi oleh buruh tani yang berjumlah 2.125 Orang. Jumlah Penduduk Menurut Agama Yang dianut dari Agama Islam berjumlah 6.063 Orang dan Katolik 5 Orang. Berdasarkan Mata Pencaharian Petani berjumlah 2.125 Orang, Pedagang berjumlah 250 Orang, Pegawai Negeri Sipil berjumlah 9 Orang, TNI / POLRI berjumlah 4 Orang, Pensiunan / Purnaawirawan berjumlah 4 Orang, Buruh Pabrik berjumlah 88 Orang, Pengraajin berjumlah 40 Orang, Tukang Bangunan berjumlah 30 Orang, Penjahit berjumlah 5 Orang, Tukang Ojek berjumlah 60 Orang, Bengkel berjumlah 7 Orang, Sopir berjumlah 35 Orang dan Lain-Lain berjumlah 200 Orang. KKN dilaksanakan mulai tanggal 7 Agustus - 3 September 2018 dengan sasaran warga Kampung Moyan RT 10/RW 05 diantaranya siswa-siswi MI Sunanul Huda, SD Dukuh 01, PAUD Riyadul Hasanah, Tempat Pembuangan Akhir, ibu-ibu kader, ibu-ibu pengajian majelis ta'lim Nuru Sa'adah.

\section{METODE}

Metode penelitian adalah cara utama yang digunakan dalam proses pengumpulan dan analisis data yang dilakukan secara sistematis dan logis untuk mencapai tujuan tertentu. Metode yang dilakukan dalam pelaksanaan rangkaian program KKN Tematik 2018 oleh kelompok 30 yaitu dengan cara wawancara terhadap tokoh masyarakat dan pegawai kantor desa di Desa Galuga. Wawancara adalah cara menghimpun bahan - bahan keterangan yang dilaksanakan dengan tanya jawab secara lisan, sepiak, berhadapan muka dan dengan arah tujuan yang telah ditentukan. Ada dua jenis wawancara yang dapat dilakukan dalam 
kaitannya dengan pengumpulan data penelitan yaitu Wawancara terpimpin (guide interview) yang juda dikenal dengan sebutan wawancara berstruktur atau wawancara sistematis. Wawancara tidak terpimpin (un-guided interview) yang dikenal dengan istilah wawancara sederhana atau wawancara bebas. Peneliti juga melakukan observasi langsung kepada masyarakat sebagai suatu kegiatan membandingkan fakta dan budaya yang ada dilingkungan setempat. Observasi adalah adalah cara meghimpun bahanbahan keterangan yang dilakukan dengan mengadakan pengamatan dan penacatatan secara sistematis terhadap fenomena fenomena yang diajdikan obyek penelitian.

Peneliti melakukan pendekatan terhadap masyarakat Desa Galuga, dimulai dengan Pegawai Kantor Desa, Tokoh Masyarakat, Ibu-ibu, Bapak-bapak, anakanak dan masyarakat Desa Galuga. Peneliti juga melakukan sosialisasi dan penyuluhan kepada masyarakat sesuai program yang sudah di rencanakan.

\section{REALISASI PROGRAM}

Realiasasi Program Mahasiswa KKN dilaksanakan selama kurang lebih 30 hari terhitung sejak tanggal 7 Agustus 2018 sampai dengan 5 September 2018. Berikut ini adalah laporan berbagai kegiatan yang telah dilaksanakan oleh mahasiswa KKN di Desa Gunung Bunder II, Kecamatan Pamijahan, Kabupaten Bogor yang dilaksanakan oleh enam divisi yaitu: Divisi Pendidikan, Divisi Kesehatan Masyarakat, Divisi Ekonomi, Divisi Agama, Divisi Hukum, Divisi Teknik total jumlah 25 program kerja terlaksana dan 2 program kerja tambahan.
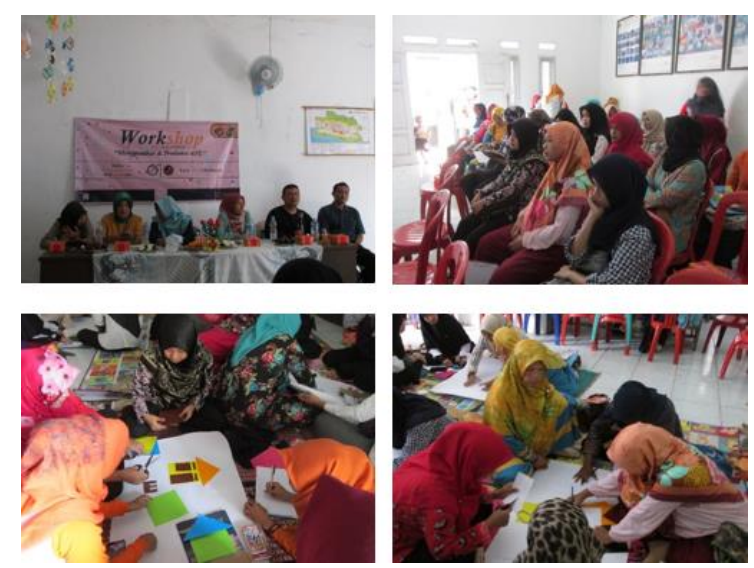

1. Pelatihan Menggambar dan Produksi APE.

Pelatihan Menggambar dan Produksi APE dilakukan pada Tanggal 01 September 2018 di Aula desa Galuga. Dengan mengundang 2 Pemateri dari Alumni UIKA Bogor dan 2 gugus Tutor PAUD dari desa Galuga. Program bertujuan untuk meningkatkan mutu guru PAUD dalam menggambar dan pembuatan alat peraga edukatif. Agar guru memiliki keahlian lebih dalam menggambar dan guru bisa membuat siswa termotifasi mengikuti proses pembelajaran dikelas ketika guru bisa membuat alat peraga edukatif yang menyenangkan bagi peserta didik.
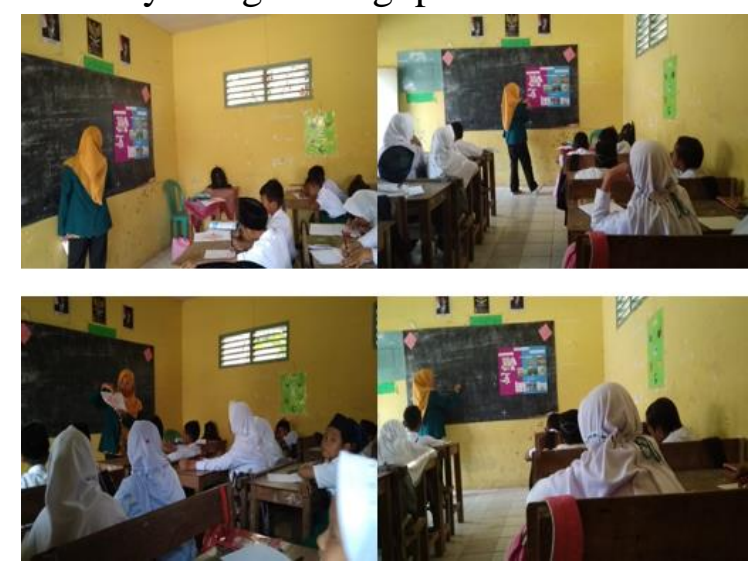

2. Pelatihan Metode Pembelajaraan Aktif Learning.

Program ini dilakukan agar anak dapat menggunakan metode lain. Pembelajaran Aktif learning yang dilakukan type index card match. Pembelajaran aktif type index card 
match ini dilakukan dengan cara mencari pasangan kartu yang sesuai antara pertanyaan dan jawaban. Pelatihan ini bertujuan untuk meningkatkan motivasi siswa pada saat proses pembelajaran berlangsung, supaya siswa tidak jenuh ketika belajar di kelas, membuat siswa lebih aktif dalam proses pembelajaran Methode ini menuntut siswa aktif ketika proses pembelajaran. Penggunaan metode ini dilakukan di MI Sunanul Huda di kelas 6.

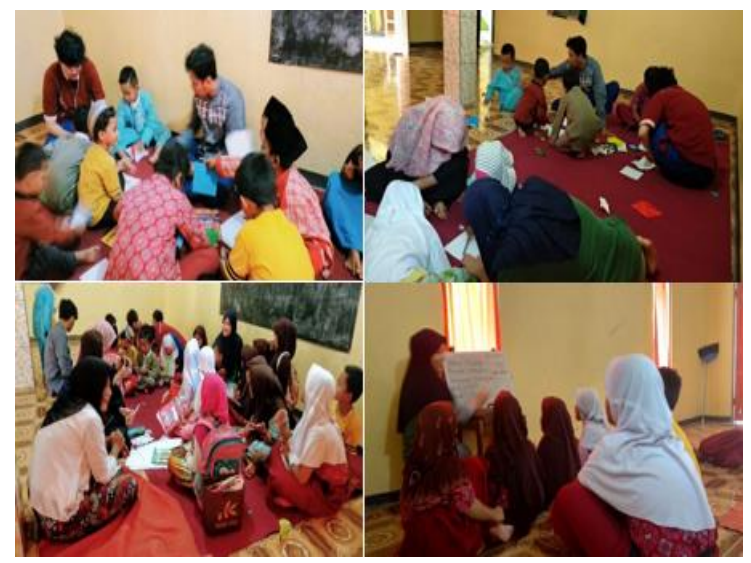

3. Bimbingan Belajar Pintar.

Bimbingan belajar ini merupakan program untuk membantu dalam memahami pelajaran dam membantu menyelesaikan pekerjaan rumah siswa/i Kp. Moyan desa Galuga. Bimbingan belajar ini dilaksanakan setiap hari jum'at pada tanggal 10, 24, 31 Agustus di Majelis Kp. Moyan dengan durasi 60 menit. Bimbel yang diadakan untuk SD/MI seperti pelajaran matematika, bahasa inggris. Untuk TK/PAUD seperti membaca, menulis dan berhitung. Bimbel anak-anak dilakukan di majlis yang berada di RW 05, RT 10. Pelaksanaan bimbel dilakukan seminggu satu kali tepatnya pada hari jum'at pukul 13.00.

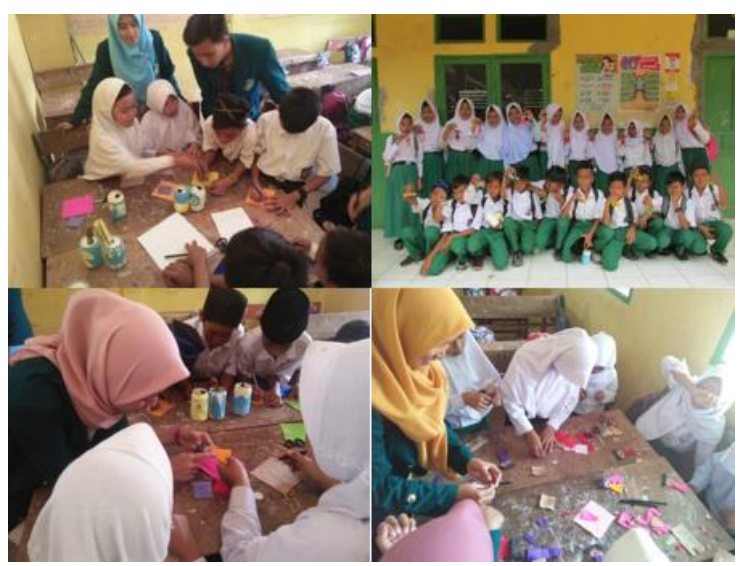

4. Kreatifitas Tanpa Batas.

Pelatiahan ini dilakukan untuk melatih kreatifitas anak-anak, melatih daya fikir anak-anak dan agar peserta didik kelak dapat lebih kreatif membuat suatu prodak yang bisa diusahakan dengan baik. Pelatihan ini untuk dasar mengenalkan peserta didik dalam pembuatan kreatifitas yang menyenangkan. Program ini dilakukan pada hari senin bersamaan dengan program Tabungan sekolah. Dimana siswa diajak untuk berkreatif sesuai dengan kemampuannya. Anak - anak dipandu oleh mahasiswa dan mereka mengikuti dengan baik. Untuk perempuannya mereka membuat gantungan orang - orangan, sedangkan yang laki- lakinya membuat gantungan mobil - obilan. Jumlah peserta yang mengikuti sekitar 26 siswa di MI Sunanul Huda.

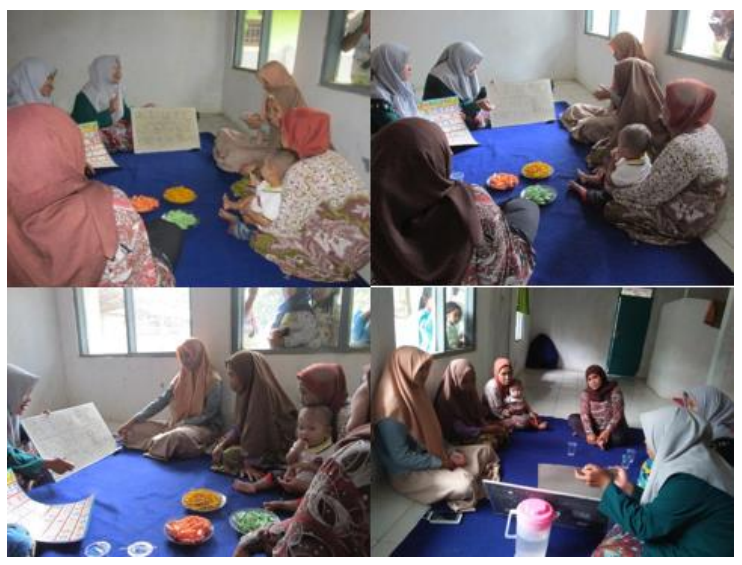

5. Keaksaraan Usaha Mandiri 
Pelatihan keaksaraan merupakan pelatihan yang dilakukan untuk membantu orang tua yang tidak mengenal huruf. Kegiatan Pelaksanaan ini, dilakukan pada hari Minggu dan Selasa siang, bertempat di mushola alikhlas. Di Kp. Moyan sebagian warga tidak bisa membaca, dan mengikuti kegiatan kemarin hanya dua orang.

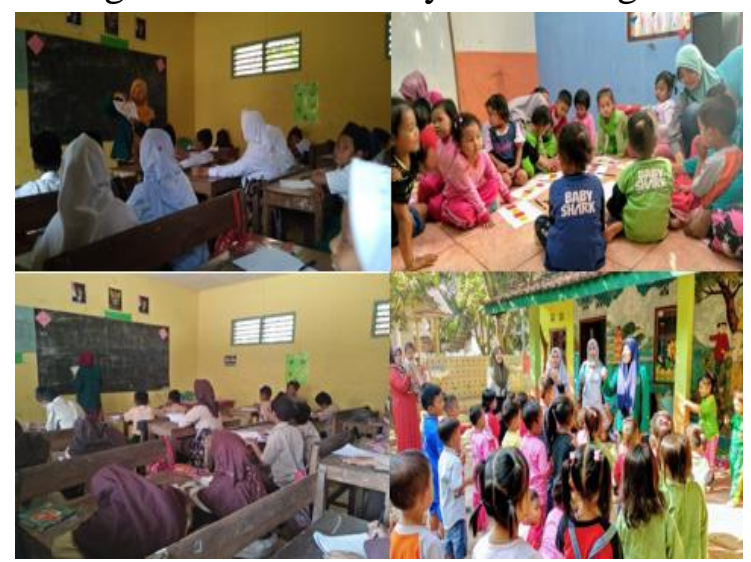

6. Bantuan Mengajar.

Kegiatan ini dilakukan dengan tujuan membantu dalam penyelenggaraan PAUD dan MI, yang dimana kurangnya tenaga pengajar di PAUD dan MI tersebut.

Kegiatan Belajar Mengajar di MI dilakukan di kelas 3,4,5,6. Pembelajaran yang dilakukan yaitu dalam pelajaran IPA, Matematika, Aqidah Akhlaq, Fiqih dan Bahasa Arab.

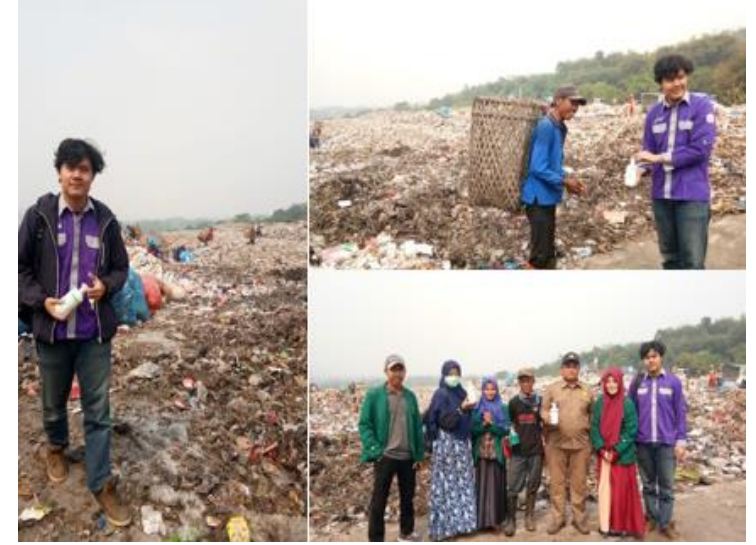

7. Penyuluhan cuci tangan.

Penyuluhan ini dilakukan di MI Sunanul Huda dan TPA. Penyluhan ini dimaksudkan untuk menumbuhkan kesadaran dan meningkatkan wawasan bagi anak-anak usia dini untuk pentingnya hidup sehat dan agar dapat menjaga kesehatan dari cara mencuci tangan yang benar sebelum melakukan aktivitas sehari-hari. Menurut Eska dalam Jurnal Abdi Dosen Pemberdayaan kesehatan merupakan kegiatan penambahan pengetahuan yang diperuntukan bagi masyarakat melalui penyebaran pesan. Program (Mencuci tangan dengan air yang mengalir) yang baik dan benar ialah antusias siswasiswi dan para pekerja di TPA dalam kegiatan penyuluhan sangat baik. Mereka menanggapi pertanyaan dari pemateri dan berani melakukan demo sikat cuci tangan yang baik dan benar.

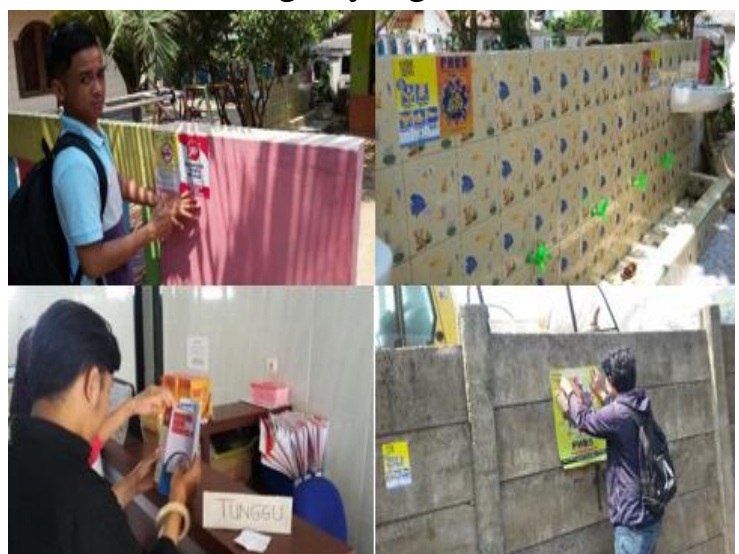

8. Media Promosi Kesehatan.

Media Kesehatan ini unuk mempermudah warga setempat untuk melakukan hidup sehat. Dengan media tersebut dapat meningkatkan pengetahuannya yang akhirnya diharapkan dapat berubah perilakunya kearah positif terhadap kesehatannya. Program dari penyuluhan ini ialah lembaga kesehatan POSYANDU, PUSKESDES, KLINIK DAN BIDAN dengan senang hati menerima media tersebut dan juga masyarakat dapat mendapatkan pengetahuan dari media tersebut. Penyebaran media tersebut 
juga disebar ke TPA dengan izin anggota dari dinas kebersihan.

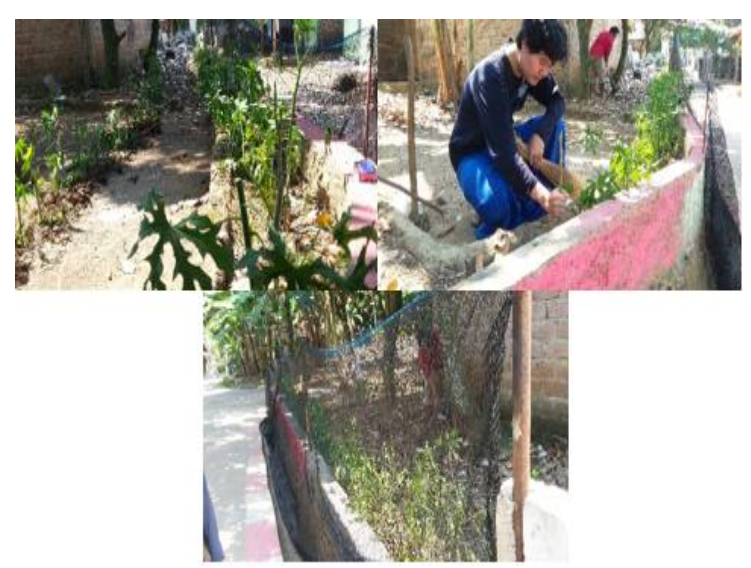

9. Demonstrasi Plat TOGA (tanaman obat keluarga).

TOGA adalah Tanaman Obat Keluarga yang dimanfaatkan sebagai tanaman alternatif di Kp. Moyan. Program ini adalah masyarakat memberikan respon positif kepada kami, dan pada waktu singkat dapat di manfaatkan tanaman tersebut dengan sebaik-baiknya.

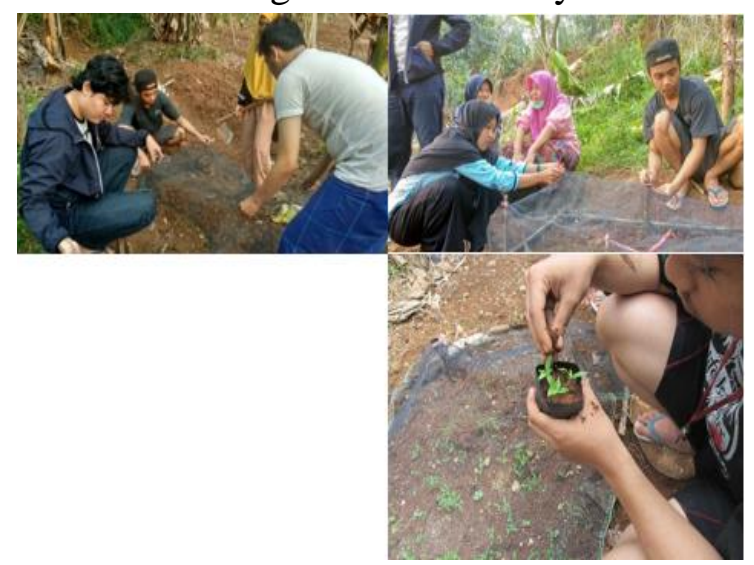

10. Tabungan Pohon Cabai.

Program Tabungan Pohon Cabai dilaksanakan sejak tanggal 12 Agustus sampai 2 September 2018. Program ini dilakukan di lahan warga terlebih dahulu dengan melakukan penyemaian. Bibit cabai tumbuh sekitar dua sampai tiga minggu untuk dapat dipindahkan ke polybag. Dengan sasaran bibit pohon cabai dibagikan ke masyarakat sekitar kp. Moyan Desa Galuga bogor. Tujuan dari peogram kerja ini adalah guna menurunkan daya konsumtif masyarakat terutama ibu-ibu dalam berbelanja kebutuhan masak dan tumbuhan yang kelak bisa dijual dan uangnya digunakan untuk biaya pendidikan.

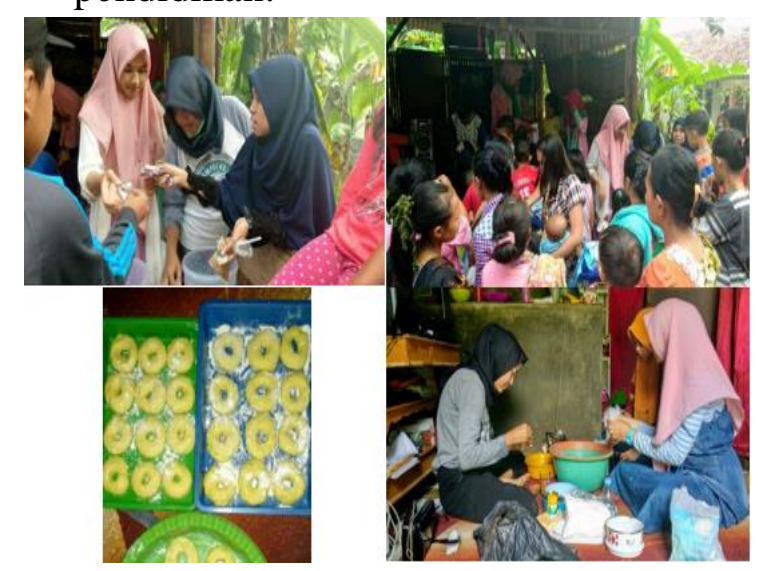

11. Bazar Celah Potensi UMKM.

Program Bazaar Celah Potensi UMKM dilaksanakan pada tanggal 29 Agustus 2018. Program ini dilakukan di depan pos ronda warga desa kp. Moyan RT.10/RW.05. Dengan sasaran para pemuda dan bapa-bapa. Tujuan dari program kerja ini adalah guna mendorong masyarakat Desa Galuga untuk menjadi pengusaha dalam UMKM dan untuk memancing masyarakat untuk berwirausaha dengan memunculkan ide ide yang lebih inovatif.

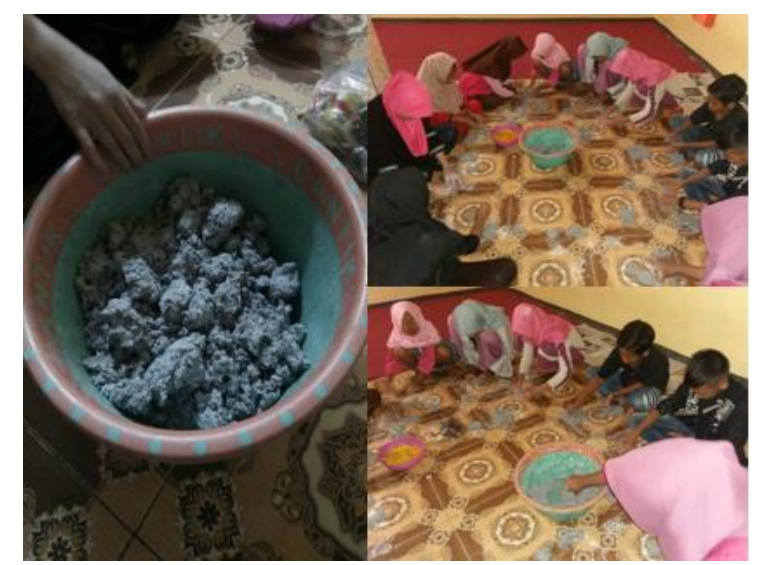

12. Pelatihan Daur ulang.

Program Daur Ulang kertas bidik manfaat ekonomi dilaksanakan pada 
tanggal 28 Agustus 2018. Program ini dilakukan di Majlis Nurrusa'ada. Dengan sasaran Ibu-Ibu dan warga sekitar Kp. Moyan Desa Galuga. Tujuan dari program kerja ini adalah secara ekonomis daur ulang kertas bekas dapat mengurangi potensi biaya yang ditimbulkan sampah, sekaligus mendatangkan potensi pendapatan dari berbagai produk yang dibuat dari hasil daur ulang.

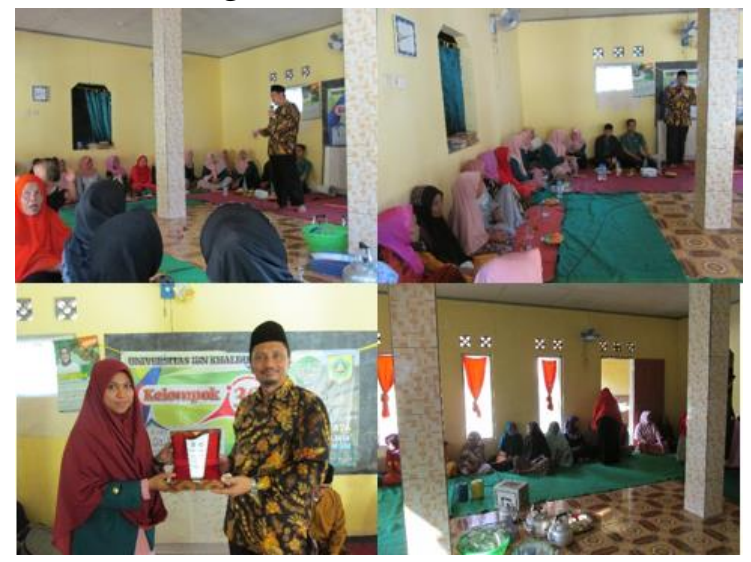

13. Penyuluhan Ekonomi Syariah.

Program Penyuluhan Ekonomi Syariah dilaksanakan pada tanggal 31 Agustus 2018. Program ini dilakukan di Majlis Nurrusa'ada. Dengan sasaran Ibu-Ibu dan warga sekitar Kp. Moyan Desa Galuga. Tujuan dari program kerja ini adalah agar warga desa Galuga menjadi tahu akan dampak buruk dari penggunaan pinjam terhadap rentenir yang menjadi riba, tahu akibat dari dosa riba, menjadi tahu cara menggadaikan barang berharga yang sesuai syariat Islam dan melakukan jual beli yang disyariatkan dalam Islam agar memperoleh ridha Allah SWT.

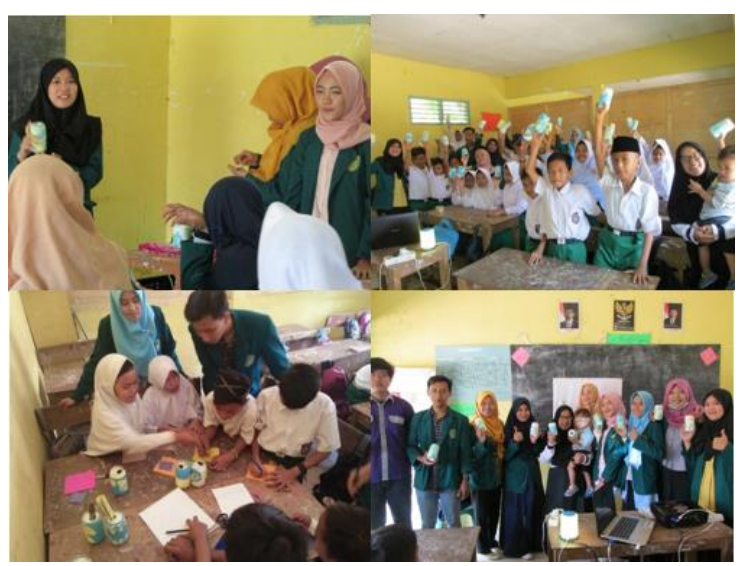

14. Tabungan Bekal Sekolah (TBS).

Program Tabungan Bekal Sekolah (TBS) dilaksanakan pada tanggal 27 Agustus 2018. Program ini dilakukan di sekolah MIS Sunanul Huda. Dengan sasaran anak usia dini atau pelajar. Tujuan dari program kerja ini adalah kami melihat masyarakat khususnya anak-anak memiliki sifat konsumerisme yang sangat tinggi. Dari latar belakang tersebut kami tegerak untuk membuang sifat konsumtif dan merubah pola fikir mereka sejak usia dini dengan mengajak atau memberi motivasi untuk senantiasa menabung. Dan mereka bisa membeli peralatan sekolah mereka dari hasil tabungan mereka sehingga dapat meringankan beban orangtua mereka.

15. Gerakan Sholat subuh berjamaah.

Program Gerakan Shalat Shubuh Berjama'ah dilaksanakan pada tanggal 8 Agustus sampai 5 September 2018. Program ini dilakukan di Mesjid. Dengan sasaran bapak-bapak dan warga sekitar Kp. Moyan Desa Galuga. Tujuan dari program kerja ini adalah program ini hanya membantu warga $\mathrm{kp}$. Moyan agar lebih semangat dalam melaksanakan shalat shubuh dan tepat waktu untuk berjamaah di Mesjid. 


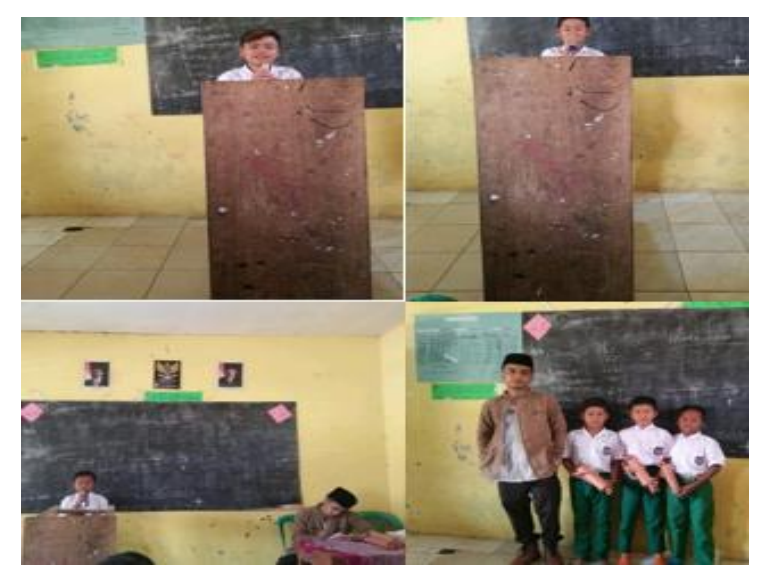

16. Lomba adzan

Tujuan lomba ini supaya anak didik agar tebiasa untuk tampil didepan umum dan Percaya diri. Dan lebih berani untuk mendemonstrasikan di masjid - masjid dideket rumahnya.

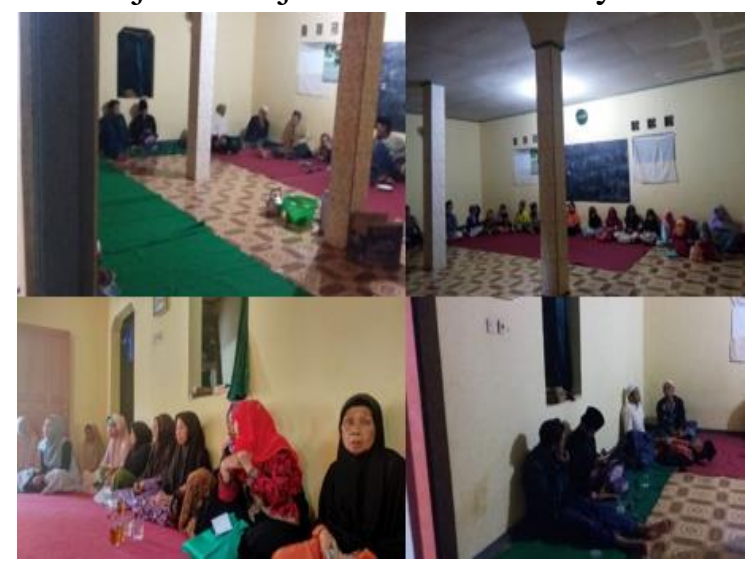

17. Pengajian Kp. Moyan.

Program Pengajian Kp. Moyan Bapakbapak dan Ibu-ibu dilaksanakan setiap 1 minggu sekali dimulai dari tanggal 8 Agustus sampai 5 September 2018. Kalau bapak-bapak pengajiannya dilaksanakan setiap hari kamis pukul 19.00-21.00 WIB. Sedangkan untuk ibu-ibu dilaksanakan setiap hari jum'at pukul 07.30-10.00 WIB Program ini dilakukan di sekolah Majlis Nurussa'adah. Dengan sasaran bapakbapak dan ibu-ibu. Tujuan dari program kerja ini adalah mendekatkan diri dengan masyarakat sekitar agar mudah berinteraksi dan menjaga silahtuhrahmi dengan ibu-ibu ataupun dengan bapakbapak desa Galuga

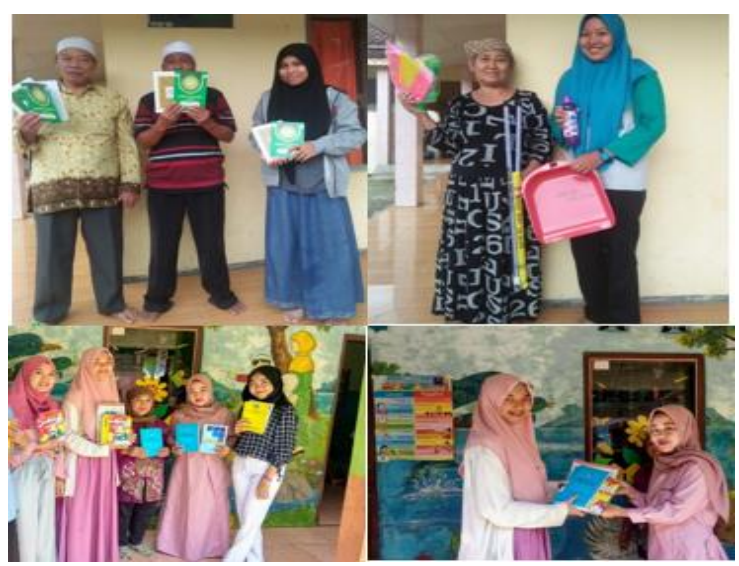

18. Infaq Al-Quran, Iqra dan Buku.

Program pelatihan metode iqra dilaksanakan setiap setelah shalat maghrib bersama ustadz setempat. Dimulai dari tanggal 8 Agustus sampai 3 September 2018. Sasaran yang dilakukan ialah anak usia 8-13 tahun. Program ini dilakukan di Majlis Nurussa'adah. Tujuan dari program kerja ini adalah agar lebih mudah membaca Al-Qur'an maupun surahsurah pendek dengan metode iqra yang praktis dalam membacanya. Karena di desa Galuga masih menggunakan Fatah Tain belum menggunakan Iqra.

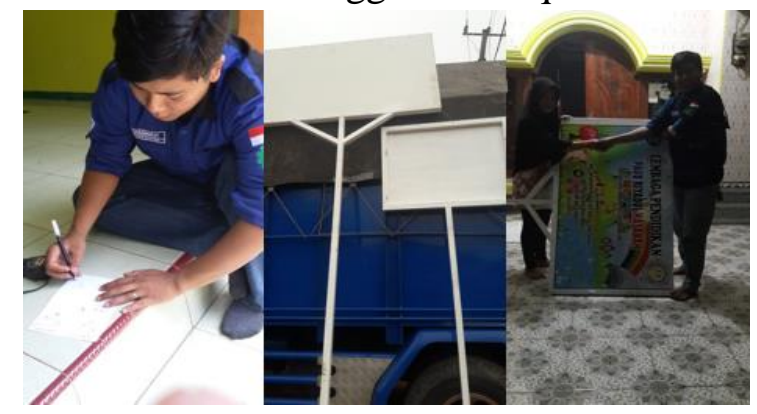

19. Pembuatan Plangnisasi.

Pembuatan Plang PAUD dan Mesjid untuk membantu Fasilitas yang kurang di Kp. Moyan Desa Galuga. Program ini dilakukan dengan maksud sebagai petunjuk tata leatak lokasi - lokasi Mesjid dan PAUD yang ada di Kp. Moyan agar lebih memudahkan masyarakat asli Kp. Moyan atau pun Luar Kp. Moyan yang sedang melewati Daerah tersebut 


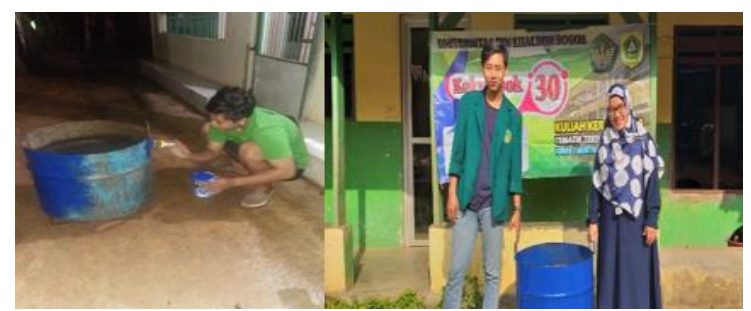

20. Pembuatan Tong Sampah.

Walaupun Desa Galuga dikenal sebagai Tempat Pembuangan Akhir, namun tepat di Kp. Moyan sendiri belum banyak memilik tempat sampah alternatif. Dengan adanya kegiatan ini, dimaksudkan agar masyarakat menyadari pentingnya penyedian tempat sampah dengan cara menyediakan beberapa tong sampah di sekitar masjid, PAUD, Warung, MCK dll.

21. Pembuatan Logo Sekolah. Untuk membantu perlengkapan PAUD Riyadul Hasanah. Dan sebagai tanda Pembeda antar lembaga satu dengan yang lainnya.
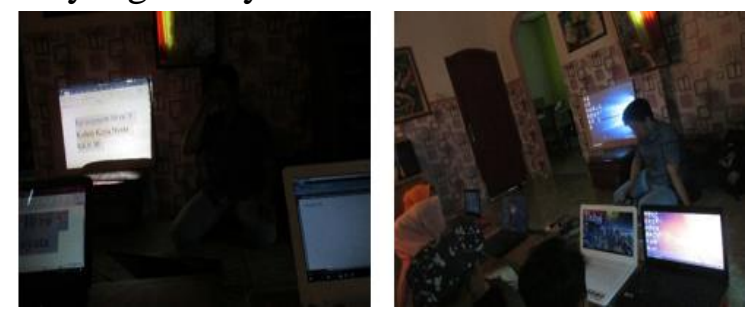

22. Pelatihan Software.

Pelatihan ini di tujukan kepada guru paud yang mengajar di Desa Galuga Kp.Moyan rt 5 rw 10 dimana pelatihan ini bertujuan untuk memberikan wawasan lebih dan meningkatkan kemampuan guru paud khususnya dalam bidang computer. Pelatihan ini dilakukan di PAUD Riyadul Hasanah pada Hari Jumad pukul 13.00. kegiatan ini diikuti oleh semua tenaga pengajar yang ada di PAUD tersebut Sebanyak 5 orang. Pelatihan Software ini dimana mahasiswa mengajarkan kepada guru cara membuat buku Tamu, Buku Absen
Siswa dan Guru dengan menggunakan Ms. Word

23. Pengecatan Makam.

Program ini dilakukan untuk memperimdah Kp. Moyan dengan warna cat yang sesuai agar Makam di Kp. Moyan terlihat bersih, rapih, indah dan memberi warna yang indah dari sebelumnya

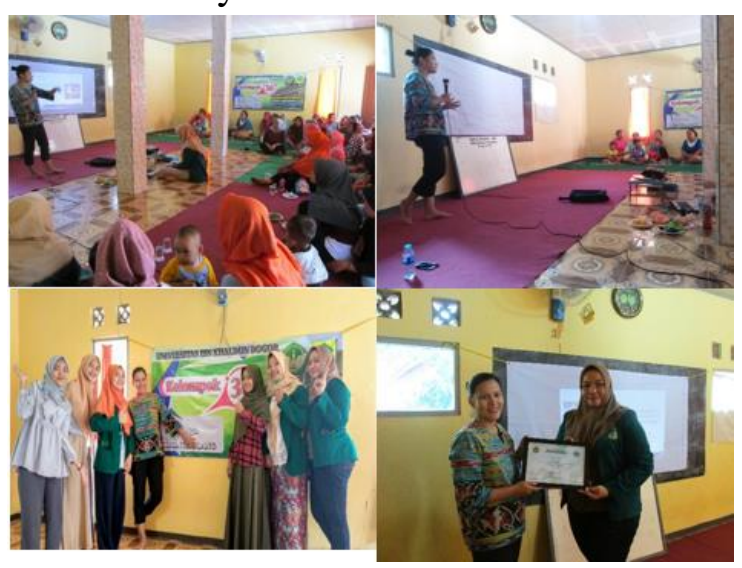

24. Penyuluhan Hukum KDRT.

Kegiatan memberikan nilai positif kepada ibu - ibu dan juga memberikan manfaat terhadap pengetahuan tambahan tentang perlindungan hukum didalam rumah tangga khususnya Perlindungan dari Korban KDRT dan Peran dari Komnas Perlindungan Perempuan sebagai lembaga negara yang independen untuk penegakan hak asasi manusia perempuan Indonesia. Hari Minggu Tanggal, 02 Agustus 2018 pukul 10.00 - 12.00 WIB di Mejelis Ta'lim Nurul Saa'da RT.10 RW 05 Kampung Moyan, Desa Galuga, Kabupaten Bogor.

\section{Program Tambahan.}




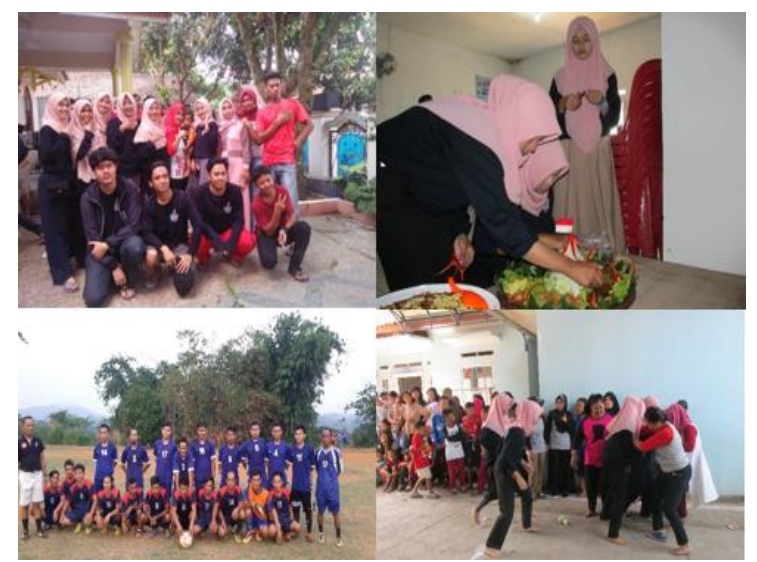

a. Pendampingan Kegiatan 17 Agustus

Lomba 17 Agustusan merupakan suatu kegiatan yang bertujuan untuk menjalin rasa gotong royong dan kebersamaan tehadap sesama masyarakat. Dan membangkitkan rasa patriotisme atau jiwa perjuangan dalam memperingati Hari Ulang Tahun Republik Indonesia di Desa Galuga khususnya di Kp.Moyan.

b. Pembentukan Ikatan Remaja Kp. Moyan (IRAMOY).

Sebagai wadah ajang kreatiftas anak muda, dalam rangka meningkatkan kreatifitas mereka. Serta sebagai wadah silaturahmi antara pemuda di Kp. Moyan. Juga berfungsi sebagai tempat bertukar pikiran antara pemuda dan pemudi.

\section{KESIMPULAN}

Kuliah kerja nyata (KKN) adalah bagian dari system pendidikan tinggi yang menempatkan mahasiswa di luar kampus agar mahasiswa hidup ditengah-tengah masyarakat, bersama masyarakat untuk membantu dan mendampingi masyarakat memanfaatkan potensi sumber daya alam local dan sumber daya manusia yang ada untuk mengatasi permasalahan masyarakat dalam kurun waktu tertentu.

$$
\text { KKN Tematik Terintegrasi }
$$

Universitas Ibn Khaldun Bogor bagi masyarakat yakni untuk meningkatkan kesadaran masyarakat dengan berperan aktif dalam mengembangkan produktifitas sumberdaya pembangunan sesuai dengan fasilitas yang dimiliki.

Sesuai dengan tujuan dari kegiatan KKN Tematik Terintegrasi Universitas Ibn Khaldun Bogor. Kelompok KKN 30 mengadakan program kerja dalam bidang pendidikan, kesehatan, ekonomi, teknik dan hukum

\section{SARAN}

KKN Tematik Terintegrasi Universitas Ibn Khaldun Bogor bagi masyarakat yakni untuk meningkatkan kesadaran masyarakat dengan berperan aktif dalam mengembangkan produktifitas sumber daya pembangunan sesuai dengan fasilitas yang dimiliki. Sesuai dengan tujuan dari kegiatan KKN Tematik Terintegrasi Universitas Ibn Khaldun Bogor. Kelompok KKN 30 mengadakan program kerja dalam bidang Pendidikan, Kesehatan, Ekonomi, Teknik dan Hukum. Dengan adanya Program Kerja ini, Kami berharap agar masyarakat dapat melanjutkan program-program yang telah dilaksanakan oleh mahasiswa KKN Universitas Ibn Khaldun Bogor. 


\section{REFERENSI}

Administrasi profil desa

Arief A Zainal. (2016). Metodologi Penelitian. Bogor : UIKA PRESS

Eska Perdana Prasetya (2017), Pemberdayaan Masyarakat Tentang Kesehatan, Pendidikan Dan Kreatifitas, Jurnal Abdi Dosen

Silberman, Melvin L., Active Learning 101 Cara Belajar Siswa Aktif, Bandung : Nusamedia, 2006, Cet III 